\title{
Do Pre-Sale and Post-Sale Foreclosure Statutes Impact Foreclosure Starts?
}

\author{
Russell Price, Debby Lindsey-Taliefero, Lynne Kelly, William Brent \\ Department of Finance, School of Business, Howard University, Washington DC, USA \\ Email: r_price@Howard.edu, dlindsey@howard.edu, ljkelly@Howard.edu, wbrent@Howard.edu
}

Received 17 March 2015; accepted 12 June 2015; published 16 June 2015

Copyright (C) 2015 by authors and Scientific Research Publishing Inc.

This work is licensed under the Creative Commons Attribution International License (CC BY). http://creativecommons.org/licenses/by/4.0/

(c) (7) Open Access

\begin{abstract}
This paper examines the impact of state laws on foreclosure starts using mortgage, borrower, and economic data at the state level. Several models are studied to capture the impact of state-specific foreclosure laws and statutes, i.e. loss mitigation requirement before foreclosure, right to cure, and right to reinstate before sale. Data sources include Mortgage Bankers Association, Home Mortgage Disclosure Act, US Census, National Consumer Law Center-Survey of State Foreclosure Laws, and Experian. The study shows that statewide pre- and post-sale foreclosure-prevention statutes impact foreclosure starts. The results indicate statutory programs involving housing emergency assistance funds statistically slow foreclosure starts.
\end{abstract}

\section{Keywords}

Foreclosures, State Foreclosure Laws, Recourse, Nonrecourse, Foreclosure Statutes

\section{Introduction}

The Mortgage Bankers Association (MBA, 2014) chief economist notes major improvement in mortgage market performance, which is directly related to a strong job market, tighter credit standards, lower delinquency rates and increasing home prices. The increase in home value has helped build an equity cushion for many new borrowers and has enabled some homeowners who had been underwater to regain positive equity in their properties. Foreclosure starts have declined for five of the last six quarters, and the percentage of loans in foreclosure has decreased for eight straight quarters. The rate of new foreclosure starts, which captures the flow of loans that enter the foreclosure process, is now at 0.45 percent, which matches the long-run average. The MBA cautioned that national improvements may not always translate into state or local market improvements. As an example, during first quarter of 2014, four states had an increase in the rate of new foreclosures started, and one state had an increase in loans in foreclosure. 
The National Delinquency Survey Data (MBA, 2014) indicate that judicial states continue to account for the majority of loans in foreclosure, making up almost 70 percent of loans in foreclosure, while only representing about 40 percent of loans serviced. Of the 17 states that had a higher foreclosure inventory rate than the national average, 15 of those were judicial states. While the percentages of loans in foreclosure dropped in both judicial and non-judicial states, the average rate for judicial states was 4.6 percent compared to the average rate of 1.4 percent for non-judicial states. New Jersey, a state with a judicial foreclosure system, was the only state in the nation to see an increase in loans in foreclosure over the previous quarter and now has the highest percentage of loans in foreclosure in the nation with eight percent of its loans in the foreclosure process. New Jersey also had the highest percentage of new foreclosures started in the first quarter of 2014, but also had a significant drop in its loans that were $90+$ days delinquent, a sign that a large portion of loans previously held in the 90+ day delinquency category entered the foreclosure process during the first quarter of 2014. The New Jersey scenario provides evidence that the parts do not reflect the whole. As a result, further study of judicial influence on state foreclosure rates is needed. This paper examines the impact of state foreclosure statutes on the rate of foreclosure starts for 50 states and the District of Columbia by introducing variables for pre- and post-sale protection statues into regression models for state foreclosure rates.

\section{Literature Survey: Foreclosure and Mortgages}

\subsection{Pre-Mortgage Crisis Studies}

The debate over foreclosure laws and their impact on the mortgage market has intensified in the past 15 years. In 1990, Clauretie and Herzog studied the impact of state foreclosure laws on residential mortgage risk. They found that a judicial procedure and statutory right of redemption lengthened the foreclosure and liquidation process and added to loan losses.

Schill (1991) examined whether mortgagor protection laws can be justified as promoting economic efficiency by acting as a form of insurance against the adverse effects of default and foreclosure. The costs of mortgagor protection laws were examined by a net present value simulation model of mortgage lending. The simulation results indicated that home mortgage loan interest rates are relatively insensitive to the existence of mortgagor protection laws and that the incremental costs of these laws are likely to be quite modest. In addition, a multiple regression model was used to estimate the effect of state mortgagor protection laws on state interest rates. The regression results are consistent with the net present value simulation. Mortgagor protection laws have a much smaller effect on state interest rates than previous studies indicate.

Baker, Miceli and Sirmans (2008) developed an economic analysis of mortgage redemption laws in the United States. Their paper develops a theory that explains these laws as a means of protecting landowners against the loss of non-transferable values associated with their land. A longer redemption period reduces the risk that this value will be lost but also increases the likelihood of default. The optimal redemption period balances these effects. Empirical analysis of cross-state data from the early twentieth century suggests that these factors, in combination with political considerations, explain the existence and length of redemption laws.

Pence (2006) hypothesized that in states with laws favoring the borrower, the supply of mortgage credit may decrease because lenders face higher costs. To examine the laws' effects, Pence compared approved mortgage applications in census tracts that border each other but are located in different states and faced different foreclosure laws. Using a regression-discontinuity design and semi-parametric estimation methods, the study found that loan sizes are 3 to 7 percent smaller in defaulter-friendly states, which suggests that defaulter-friendly laws impose material costs on borrowers at the time of loan origination.

\subsection{Post-Mortgage Crisis Studies}

Quercia and Ding (2009) studied loss mitigation by examining the relationship between re-default rates and different types of loan modifications based on a large sample of recently modified loans. Their findings showed that the key component to making modified loans more sustainable is a reduction in mortgage payments that are large enough for the housing to be truly affordable to the borrowers. The findings also confirmed that an even lower likelihood of re-default was possible when the payment reduction is the result of writing down the principal.

Using a national loan-level dataset Goodman and Smith (2010) examined loan default as explained by state- 
wide foreclosure procedures, using a hierarchical linear model. When controlling for loan and local conditions, they observed significant variation in the default rate across states, with lower default levels in states with higher temporal and financial costs to lenders.

Collins, Lam and Herbert (2011) studied the extent to which distressed mortgage borrowers benefit from three types of state foreclosure polices: 1) judicial foreclosure proceedings, 2) statutory rights of redemption, and 3) statewide foreclosure-prevention initiatives. The analysis was based on borrowers in default residing in 22 matched paired cross-state metropolitan statistical areas. The results indicated that state policies generally have weak effects. Both judicial foreclosure proceedings and foreclosure prevention initiatives were associated with modest increases in loan modification rates. In addition, the promotion of mortgage default counseling was associated with increases in loan modifications, decreases in loan cures, and decreases in foreclosure starts. The effects of the latter were also stronger in states with judicial proceedings.

Koc, Dudley and James (2014) examined how judicial review requirements, lenders' recourse rights (deficiency judgments), and state assistance programs for distressed borrowers affected the likelihood of default during the recent U.S. housing crisis. They argued that state foreclosure laws should have little effect on the likelihood of liquidity events (for example, shocks to borrowers' ability to make payments) and thus provide a good instrument for identifying borrowers' costs of default. The authors found that borrowers with negative home equity are significantly more likely to default in states with borrower-friendly foreclosure laws.

The current body of literature provides a framework for developing our regression models which capture the impact of pre- and post-sale foreclosure prevention statutes on foreclosure starts.

\section{Data and Methods}

This research uses data from 2004 to 2009 from the National Delinquency Survey (NDS), Home Mortgage Disclosure Act (HMDA), National Consumer Law Center-Survey of State Foreclosure Laws (SSFL), US Census, and Experian. These datasets were merged to explore the impact of pre- and post-sale state foreclosure statutes on foreclosure starts. Analyses used for statistical inference include regression analysis, Hausman test, t-test and F-test.

The National Delinquency Survey is based on a sample of approximately 45 million mortgage loans serviced by mortgage companies, commercial banks, thrifts, credit unions and others. NDS provides quarterly delinquency and foreclosure statistics at the national, regional and state levels. There are two foreclosures categories: foreclosure starts and loans currently in the foreclosure process. Our analysis focuses on foreclosure starts. Foreclosure starts measure loans that entered the foreclosure process during the reporting quarter and is a flow measure so it is seasonally adjusted.

The Home Mortgage Disclosure Act of 1975, as amended, requires many depository and non-depository lenders to collect and publicly disclose information about housing-related loans and applications for such loans, including several applicant/borrower characteristics. HMDA is implemented by the Consumer Financial Protection Bureau's Regulation C and requires lenders to report data on: 1) the loan, such as its type and amount; 2) the property, such as its location and type; 3) the disposition of the application, such as whether it was denied or resulted in an origination; and 4) the applicant (ethnicity, race, gender, and income).

The data on foreclosure laws were collected by the National Consumer Law Center (2007, 2008, 2013, \& 2014) to capture information on state initiatives involving loan modification and foreclosure diversion programs. In 2008, NCLC developed a survey designed to determine whether certain basic protections were provided for residential homeowners within each state. A few of the questions included are as follows: 1) Before losing their home to foreclosure, do homeowners have access to a court proceeding in which they can present objections and pursue options to avoid foreclosure? 2) Are mortgage holders required to engage in meaningful loss mitigation efforts before a home mortgage may be foreclosed? 3) Are homeowners given a right to cure a mortgage default for at least 60 days before the loan is accelerated and before any legal fees or foreclosure costs are incurred?

To conduct a state-level analysis, we merge NDS foreclosure rates, HMDA data, NCLC foreclosure statutes, with statewide economic indicators such as credit risk unemployment rate, construction permits, and house price index to create a comprehensive dataset. This panel dataset includes 51 cross-sectional observations (50 states plus Washington, DC) and 6 time-series observations (2004 to 2009). It is used to estimate regression models which capture the impact of pre- and post-sale foreclosure prevention statutes on foreclosure starts. The conceptual model is presented in Figure 1. 


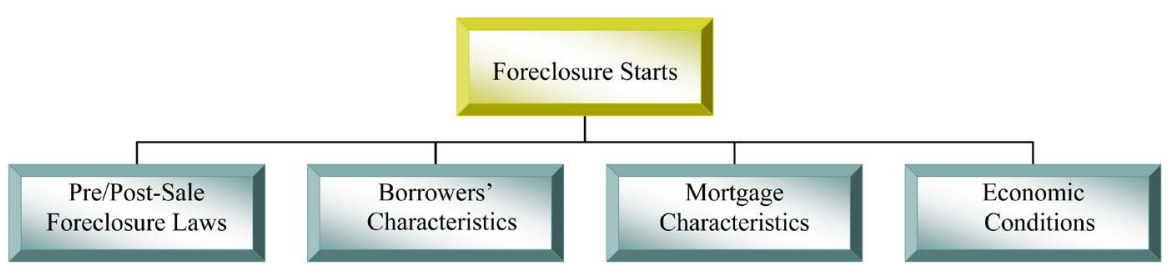

Figure 1. Conceptual model of foreclosure starts controlling for pre-sale and post- sale foreclosure statues.

Panel-data regression analysis can use either a fixed-effect or random-effect model. To determine the best modeling estimation procedure, a Hausman test was performed. The results indicate that the random-effects model is appropriate. The basic two-way random-effects model structure is

$$
\begin{gathered}
y_{i t}=\alpha+X_{i t}^{\prime} \beta+\mu_{i t}+e_{i t} . \\
u_{i t}=\gamma_{i}+v_{t} .
\end{gathered}
$$

where $y_{i t}$ is the dependent variable (Percent Foreclosure Starts), $\beta_{k}$ represents the slope coefficients that are common to all cross-sections, $X_{i t}$ are the explanatory variables (i.e., Pre- and Post-foreclosure laws/statutes, borrower characteristics mortgage characteristics and economic conditions), $\gamma_{i}$ are random parameters capturing the unobserved cross-sectional effects, $v_{t}$ are random parameters capturing the unobserved time effects, and $e_{i t}$ are the residuals which are independent and identically distributed random variables with $E\left[e_{i t}\right]=0$ and $E\left[e_{i t}^{2}\right]=\sigma_{e}^{2}$.

Percent Foreclosure Starts captured in Equation (1) are estimated for all loans, prime loans, and subprime loans and by pre- and post-sale protection foreclosure statutes.

\subsection{Foreclosure Start Rates and Independent Variables Used in the Study}

Table 1 lists the variables and their measures of central tendency used in the analysis. The time period covered is 2004 to 2009. For each year data was complied for all 50 states and the District of Columbia. The variables of key interest are the foreclosure statutes and their impact on the rate of foreclosure starts. Regulation of mortgage foreclosures has always been a fundamental province of state laws. We explore if these state laws influence foreclosure starts. The laws are grouped by pre- and post-sale statutory protections (Rao \& Walsh, 2009). The pre-sale statutory protections apply to the pre-foreclosure stage, which is often characterized as the phase where the homeowner's mortgage payments have not been made for at least 90 days. The lender records a public notice that the owner has defaulted on his mortgage, and then mails the notice to the homeowner. In some states this notice is called a Notice of Default; in others, it is a Lis Pendens. This pre-foreclosure stage is really a grace period giving the homeowner three calendar months to "cure" default. The post-sale statutory protections apply to the post-foreclosure stage, which is the phase where the property has either been purchased by a third party at the foreclosure auction or held by the lender as a bank-owned property. If the latter occurs then the property is called REO, Real Estate Owned by the lender.

The pre-sale foreclosure protection statutes included in our analysis are Access to Court Review (ARC), Loss Mitigation Requirement before Foreclosure (LMRF), Right to Cure Before Acceleration (RCBA), Right to Reinstate Before Sale (RRBS), Personal Service Requirement for Complaint or Sale Notice (PSRCSN), and Housing Emergency Assistance Fund (HEAF). Forty-three percent of all states offer ARC, which provides a judicial litigation process to foreclosure with a specific remedy. To begin a foreclosure action, the noteholder's representative files various documents with the court in the form of a "complaint". It also must serve the complaint to the homeowner, notifying him or her of ligation. About 16 percent of states make available LMRF, which permits defaulted borrowers to workout alternatives including modifications while addressing their payment delinquency. It is important to note that most of these options are voluntary, but state law and contractual arrangements, including the acceptance of Making Home Affordable (MHA) program funds from Treasury, may trigger particular loss mitigation duties on the part of the servicer. Twenty-four percent of states render RCBA, granting homeowners the right to cure a default by catching up on missed payments, without penalty, at least 60 days before a mortgage holder demands immediate full payment of the entire mortgage balance and before beginning any foreclosure proceeding. Forty-seven percent of states allow RRBS, which provides the homeowner 
Table 1. List and description of variables used to estimate impact of foreclosure laws on foreclosure rates.

\begin{tabular}{|c|c|c|c|c|}
\hline Variables & Description & Measurement & $\begin{array}{c}\text { Mean/ } \\
\text { Proportion }\end{array}$ & Source \\
\hline \multirow[t]{3}{*}{ Dependent: } & Foreclosure Starts-All Loans & $\%$ & $0.73 \%$ & $\mathrm{MBA}^{\mathrm{a}}$ \\
\hline & Foreclosure Starts-Prime Loans & $\%$ & $0.40 \%$ & MBA \\
\hline & Foreclosure Starts-Subprime Loans & $\%$ & $2.56 \%$ & MBA \\
\hline Independent: & Pre-Sale Statutory Protections & & & \\
\hline ACR & Access to Court Review & $\begin{array}{c}1=\text { recourse; } \\
0=\text { non-recourse }\end{array}$ & $43.1 \%$ & NCLC $^{\mathrm{b}}$ \\
\hline LMRF & Loss Mitigation Requirement before Foreclosure & $1=$ statute $; 0=$ no statute & $15.7 \%$ & NCLC \\
\hline RCBA & Right to Cure before Acceleration & $1=$ statute $0=$ no statute & $23.5 \%$ & NCLC \\
\hline RRBS & Right to Restate before Sale & 1 = statute; 0 = no statute & $47.1 \%$ & NCLC \\
\hline PSRCSN & Personal Service Requirement-Complaint/Sale Notice & $1=$ statute $; 0=$ no statute & $33.3 \%$ & NCLC \\
\hline HEAF & $\begin{array}{l}\text { Housing Emergency Assistance Fund } \\
\text { Post-Sale Statutory Protections }\end{array}$ & 1 = statute; $0=$ no statute & $23.5 \%$ & NCLC \\
\hline RTR & Right to Redeem & $1=$ statute $; 0$ = no statute & $41.2 \%$ & NCLC \\
\hline DJ & Deficiency Judgments & 1 = statute; 0 = no statute & $68.6 \%$ & NCLC \\
\hline ASP & Accounting of Sales Proceeds & $1=$ statute $; 0=$ no statute & $80.4 \%$ & NCLC \\
\hline \multirow[t]{2}{*}{ PRS } & Prompt Return of Surplus & $1=$ statute $; 0=$ no statute & $31.4 \%$ & NCLC \\
\hline & Borrower Characteristics & & & \\
\hline CreditScore & Average State Credit Score (FICO) & numeric & 683.82 & Experian \\
\hline INCOME & Personal Income (000) & current \$ & $\$ 36,330$ & $\mathrm{BEA}^{\mathrm{d}}$ \\
\hline FEMPCT & Primary Female-Borrowers Loans/Total Loans & $\%$ & $7.19 \%$ & HMDA $^{\mathrm{e}}$ \\
\hline WPCT & White-Borrowers Loans/Total Loans & $\%$ & $78.52 \%$ & HMDA \\
\hline ВРСТ & Black-Borrowers Loans/Total Loans & $\%$ & $5.54 \%$ & HMDA \\
\hline HISPCT & Hispanic-Borrowers Loans/Total Loans & $\%$ & $5.14 \%$ & HMDA \\
\hline ASNPCT & Asian-Borrowers Loans/Total Loans & $\%$ & $3.32 \%$ & HMDA \\
\hline \multirow[t]{2}{*}{ NTVPCT } & Native American Borrowers Loans/Total Loans & $\%$ & $0.53 \%$ & HMDA \\
\hline & Mortgage/Lending Characteristics & & & \\
\hline NIVPCT & No Income Verfication Loans/Total Loans & $\%$ & $1.91 \%$ & HMDA \\
\hline SPREAD & Loans with Spread/Total Loans & $\%$ & $17.10 \%$ & HMDA \\
\hline NONOCC & Non-Owner Occupied Loans/Total Loans & $\%$ & $12.47 \%$ & HMDA \\
\hline DENPCT & Denial Rate & $\%$ & $22.30 \%$ & HMDA \\
\hline \multirow[t]{2}{*}{ PCTADJ } & Adjustable Loans/Total Loans & $\%$ & $15.55 \%$ & FHFA $^{\mathrm{f}}$ \\
\hline & Economic Conditions & & & \\
\hline DELHPI & Change in House Price Index & $\%$ & $3.89 \%$ & FHFA $^{f}$ \\
\hline UNEMPL & Unemployment Rate & $\%$ & $5.44 \%$ & $\mathrm{BLS}^{\mathrm{g}}$ \\
\hline NBPERM & Number of Building Permits (000) & numeric & 21800.83 & BPS $^{\text {h }}$ \\
\hline
\end{tabular}

${ }^{\mathrm{a}}$ Mortgage Banker Association—MBA (2004 to 2009). National Delinquency Survey (NDS); ${ }^{\mathrm{b}}$ National Consumer Law Center—NCLC. (2007, 2008, 2013, \& 2014). Survey of State Foreclosure Laws; ${ }^{~}$ Experian (2004 to 2009). Experian Vantage Credit Score by State, based on Fair, Isaac and Com-

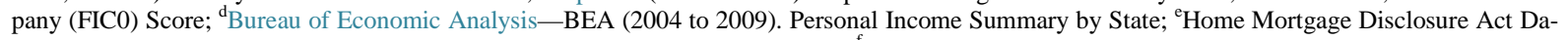
ta-HMDA. (2004 to 2009). Federal Financial Institutions Examination Council; ${ }^{\mathrm{f}}$ Federal Housing Finance Agency-FHFA, (2004 to 2009). House

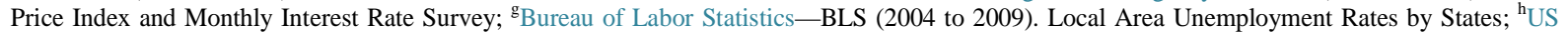
Census Bureau (2004 to 2009). Building Permits Survey (BPS).

the right to reinstate the mortgage, after the mortgage holder demands payment of the entire balance (acceleration), by paying the arrearage and reasonable foreclosure costs up to the time of reinstatement. PSRCSN requires that homeowners be personally served with the notice of sale or foreclosure complaint, 33 percent of states offer this regulation. Less than 25 percent of all states supply HEAF, which are programs that provide 
emergency financial assistance to homeowners who are facing foreclosure. These statewide programs offer temporary assistance to homeowners experiencing financial difficulties such as loss of employment, illness, disability, death, divorce or legal separation.

The post-sale foreclosure protection statutes included in our study are Right to Redeem (RTR), Deficiency Judgments (DJ), Accounting of Sales Proceeds (ASP), and Prompt Return of Surplus (PRS). Forty-one percent of states allow RTR, which provides homeowners with a statutory right to redeem and reacquire title to their home, for a fixed period of time after a foreclosure sale. Just over two-thirds of states, 68.6 percent, allow DJ, which are initiated when the foreclosure sale does not generate proceeds sufficient to satisfy the mortgage debts. A deficiency judgment is the legal ruling for the remaining amount of debt owed. A majority of states, 80.4 percent, make available ASP, which requires judicial supervision over the accounting of foreclosure sale proceeds. Less than one-third of states, 31.4 percent, require a prompt release of any surplus to the borrowers.

\subsection{Regression Results}

We organized our models by foreclosure starts by all, prime and subprime loans and isolated the impact of preand post-sale foreclosure protection statutes on foreclosure starts. Six regression models were estimated.

\subsubsection{Pre-Sale Foreclosure Protection Statutes: Foreclosure Start Regression}

Table 2 presents the regression results for foreclosure starts. The first three models incorporate the impact of pre-sale foreclosure statutes on foreclosure starts. All three models indicate that foreclosure starts can be predicted by pre-sale foreclosure protection laws, borrowers' characteristics, mortgage/lending characteristics, and economic conditions. The pre-sale statute regression results for all foreclosure starts presented in Table 2 indicate a $\mathrm{R}^{2}=0.759$, which implies that 75.9 percent of all foreclosure starts is explained by the regression model and that percent share explained is statistically significant $[(\mathrm{F}(22,283)=40.58, p<0.01]$. Two of the pre-sale protection statute variables are statistically significant, which include loss mitigation requirement $[\beta=0.255, p<$ $0.01]$ and housing emergency assistance fund $[\beta=-0.133, p<0.05]$. Four borrower characteristics are significant including income [ $\beta=-0.012, p<0.01]$, percentage of Black borrowers $[\beta=0.008, p<0.10]$, percentage of Asian borrowers [ $\beta=0.013, p<0.10]$, and percentage of Native American borrowers [ $\beta=-0.053, p<0.01]$. Five of the mortgage/lending characteristics are statistically significant which include the percentage of no income verification loans [ $\beta=-0.024, p<0.05$ ], percentage of loans with spreads [ $\beta=-0.005, p<0.01$ ], percentage of loans with non-owner occupancy [ $\beta=0.014, p<0.01]$, percentage of loans denied [ $\beta=0.126, p<0.01]$ and percentage of adjustable loans $[\beta=0.020, p<0.01]$. Two of the economic conditions are statistically significant including the change in house price index $[\beta=-0.024, p<0.01]$ and the unemployment rate $[\beta=$ $0.082, p<0.01]$.

In Table 2, the pre-sale statute regression results for prime-loan foreclosure starts indicate a $\mathrm{R}^{2}=0.717$, which implies that a 71.7 percent of prime-loan foreclosure starts is explained by the regression model and that percent share explained is statistically significant $[(\mathrm{F}(22,283)=32.51, p<0.01]$. Three of the pre-sale protection statute variables are statistically significant, which include loss mitigation requirement $[\beta=0.159, p<0.01]$, personal service requirement for complaint or sale notice $[\beta=0.100, p<0.05]$ and housing emergency assistance fund $[\beta=-0.128, p<0.01]$. Five borrower characteristics are significant including income $[\beta=-0.009$, $p<0.01$ ], percentage of white borrowers [ $\beta=0.007, p<0.05]$, percentage of Black borrowers [ $\beta=0.007, p<$ 0.05], percentage of Asian borrowers $[\beta=0.013, p<0.05]$ and percentage of Native American borrowers [ $\beta=$ $-0.031, p<0.10]$. Five of the mortgage/lending characteristics are statistically significant which include the percentage of no income verification loans [ $\beta=-0.018, p<0.05]$, percentage of loans with spreads [ $\beta=-0.005$, $p<0.01$, percentage of loans with non-owner occupancy [ $\beta=0.010, p<0.01$ ], percentage of loans denied [ $\beta=$ $0.005, p<0.10]$ and percentage of adjustable loans $[\beta=0.013, p<0.01]$. Two of the economic conditions are statistically significant including the change in house price index $[\beta=-0.015, p<0.01]$ and the unemployment rate $[\beta=0.084, p<0.01]$.

The pre-sale statute regression results for subprime-loan foreclosure starts presented in Table 2 indicate a $\mathrm{R}^{2}=0.794$, which implies that a 79.4 percent of subprime-loan foreclosure starts is explained by the regression model and that percent share explained is statistically significant $[(\mathrm{F}(22,283)=43.55, p<0.01]$. The housing emergency assistance fund $[\beta=-0.349, p<0.01]$ is the only statistically significant pre-sales protection statute Four borrower characteristics are significant including percentage of white borrowers [ $\beta=0.029, p<0.05]$, 
Table 2. Regression model for foreclosure starts by all, prime and subprime loans.

\begin{tabular}{|c|c|c|c|c|c|c|}
\hline \multirow[b]{3}{*}{$\begin{array}{c}\text { Independent } \\
\text { Variables }\end{array}$} & \multicolumn{6}{|c|}{ Regression Models } \\
\hline & \multicolumn{3}{|c|}{ Pre-Sale Protection Statutes Coefficients } & \multicolumn{3}{|c|}{ Post-Sale Protection Statutes Coefficients } \\
\hline & $\begin{array}{l}\text { All Forclosure } \\
\text { Starts }\end{array}$ & $\begin{array}{c}\text { Prime } \\
\text { Forclosure } \\
\text { Starts }\end{array}$ & $\begin{array}{l}\text { Prime } \\
\text { Forclosure } \\
\text { Starts }\end{array}$ & $\begin{array}{l}\text { All Forclosure } \\
\text { Starts }\end{array}$ & $\begin{array}{l}\text { Prime } \\
\text { Forclosure } \\
\text { Starts }\end{array}$ & $\begin{array}{c}\text { Prime } \\
\text { Forclosure } \\
\text { Starts }\end{array}$ \\
\hline Constant & 0.023 & -0.534 & $-6.639^{* *}$ & 0.015 & -0.570 & $-6.546^{* *}$ \\
\hline \multicolumn{7}{|c|}{ Pre-Sale Statutory Protections } \\
\hline SJS & -0.012 & -0.022 & 0.009 & & & \\
\hline LMRF & $0.255^{* * *}$ & $0.159^{* * * *}$ & 0.181 & & & \\
\hline RCBA & -0.043 & -0.032 & -0.099 & & & \\
\hline RRBS & 0.006 & -0.007 & -0.057 & & & \\
\hline PSRCSN & 0.076 & $0.100^{* *}$ & 0.203 & & & \\
\hline HEAF & $-0.133^{* *}$ & $-0.128^{* * *}$ & $-0.349^{* * *}$ & & & \\
\hline \multicolumn{7}{|c|}{ Post Sale Statutory Protections } \\
\hline RTR & & & & 0.057 & 0.037 & $0.227^{* *}$ \\
\hline DJ & & & & 0.027 & 0.027 & -0.010 \\
\hline ASP & & & & 0.021 & 0.069 & -0.047 \\
\hline PRS & & & & 0.073 & 0.023 & -0.008 \\
\hline \multicolumn{7}{|c|}{ Borrowers Characteristics } \\
\hline $\begin{array}{l}\text { CREDSC } \\
\mathrm{R}\end{array}$ & 0.001 & 0.000 & 0.006 & -0.001 & 0.000 & 0.007 \\
\hline INCOME & $-0.012^{* * *}$ & $-0.009^{* * *}$ & -0.002 & -0.009 & $-0.007^{* *}$ & 0.000 \\
\hline FEMPCT & 0.009 & 0.011 & 0.027 & -0.010 & -0.008 & -0.001 \\
\hline WHPCT & 0.008 & $0.007^{* *}$ & $0.029^{* *}$ & 0.006 & 0.005 & $0.026^{* *}$ \\
\hline BLPCT & $0.008^{*}$ & $0.007^{* *}$ & $0.028^{* *}$ & 0.007 & 0.007 & $0.024^{*}$ \\
\hline HISPCT & -0.005 & -0.002 & -0.007 & -0.003 & 0.000 & -0.003 \\
\hline ASNPCT & $0.013^{*}$ & $0.013^{* *}$ & $0.038^{*}$ & 0.009 & 0.009 & 0.034 \\
\hline NTVPCT & $-0.053^{* * *}$ & $-0.031^{*}$ & $-0.106^{*}$ & $-0.055^{* * *}$ & $-0.036^{* *}$ & $-0.121^{* *}$ \\
\hline \multicolumn{7}{|c|}{ Mortgage/Lending Characteristics } \\
\hline NIVPCT & $-0.024^{* *}$ & $-0.018^{* *}$ & -0.022 & -0.015 & -0.008 & $0.032^{* * *}$ \\
\hline SPREAD & $-0.005^{* * *}$ & $-0.005^{* * *}$ & $-0.020^{* * *}$ & $-0.005^{* *}$ & $-0.005^{* * *}$ & -0.007 \\
\hline NONOCC & $0.014^{* * *}$ & $0.010^{* * *}$ & $0.031^{* * *}$ & $0.013^{* * *}$ & $0.010^{* * *}$ & $0.023^{* *}$ \\
\hline DENPCT & $0.126^{* * *}$ & $0.005^{*}$ & $0.067^{* * *}$ & $0.013^{* * *}$ & $0.006^{* *}$ & $0.068^{* * *}$ \\
\hline PCTADJ & $0.020^{* * *}$ & $0.013^{* * *}$ & $0.053^{* * *}$ & $0.018^{* * *}$ & $0.010^{* * *}$ & $0.049^{* * *}$ \\
\hline \multicolumn{7}{|c|}{ Economic Conditions } \\
\hline DHPI & $-0.024^{* * *}$ & $-0.015^{* * *}$ & $-0.090^{* * *}$ & $-0.023^{* * *}$ & $-0.015^{* * *}$ & $-0.088^{* * *}$ \\
\hline UNEMPL & $0.082^{* * *}$ & $0.084^{* * *}$ & $0.068^{* *}$ & $0.081^{* * *}$ & $0.083^{* * *}$ & $0.050^{* *}$ \\
\hline NBPERM & 0.000 & 0.000 & -0.001 & 0.000 & 0.000 & 0.000 \\
\hline $\mathbf{R}^{2}$ & $0.759^{* * *}$ & $0.717^{* * *}$ & $0.794^{* * *}$ & $0.727^{* * *}$ & $0.693^{* * *}$ & $0.787^{* * *}$ \\
\hline
\end{tabular}

Note: ${ }^{*} p<0.10,{ }^{* *} p<0.05,{ }^{* * *} p<0.01$. 
percentage of black borrowers [ $\beta=0.028, p<0.05]$, percentage of Asian borrowers $[\beta=0.038, p<0.10]$ and percentage of Native American borrowers [ $\beta=-0.106, p<0.05$ ]. Four of the mortgage/lending characteristics are statistically significant which include the percentage of loans with spreads [ $\beta=-0.020, p<0.01$ ], percentage of loans with non-owner occupancy [ $\beta=0.031, p<0.01]$, percentage of loans denied [ $\beta=0.067, p<0.01]$ and percentage of adjustable loans $[\beta=0.053, p<0.01]$. Two of the economic conditions are statistically significant including the change in house price index $[\beta=-0.090, p<0.01]$ and the unemployment rate $[\beta=0.068, p<$ 0.05].

\subsubsection{Post-Sale Foreclosure Protection Statutes: Foreclosure Start Regression}

The remaining three models in Table 2 incorporate the impact of post-sale foreclosure statutes on foreclosure starts. Only the subprime model indicates that foreclosure starts can be predicted by post-sale foreclosure protection laws. Each post-sale foreclosure statute regression has borrowers' characteristics, mortgage/lending characteristics, and economic conditions. The post-sale statute regression results for all foreclosure starts presented in Table 2 indicate a $\mathrm{R}^{2}=0.727$, which implies that a 72.7 percent of all foreclosure starts is explained by the regression model and that percent share explained is statistically significant $[(\mathrm{F}(20,285)=37.89, p<0.01]$. No post-sale protection statute variables are statistically significant. Percentage of Native American borrowers $[\beta=$ $-0.055, p<0.01]$ is the only statistically significant borrower characteristic. Four of the mortgage/lending characteristics are statistically significant which include the percentage of loans with spreads [ $\beta=-0.005, p<0.05$ ], percentage of loans with non-owner occupancy $[\beta=0.013, p<0.01]$, percentage of loans denied $[\beta=0.013, p<$ $0.01]$ and percentage of adjustable loans $[\beta=0.018, p<0.01]$. Two of the economic conditions are statistically significant including the change in house price index $[\beta=-0.023, p<0.01]$ and the unemployment rate $[\beta=$ $0.081, p<0.01]$.

In Table 2, the post-sale statute regression results for prime-loan foreclosure starts indicate a $\mathrm{R}^{2}=0.693$, which implies that 69.3 percent of prime-loan foreclosure starts is explained by the regression model and that percent share explained is statistically significant $[(\mathrm{F}(20,285)=32.09, p<0.01]$. No post-sales protection statute variables are statistically significant. Two borrower characteristics are significant including income $[\beta=-0.007$, $p<0.05]$ and percentage of Native America borrowers [ $\beta=-0.036, p<0.05]$. Four of the mortgage/lending characteristics are statistically significant which include the percentage of loans with spreads $[\beta=0.005, p<$ $0.01]$, percentage of loans with non-owner occupancy $[\beta=0.010, p<0.01]$, percentage of loans denied $[\beta=$ $0.006, p<0.05]$ and percentage of adjustable loans $[\beta=0.010, p<0.01]$. Two of the economic conditions are statistically significant including the change in house price index $[\beta=-0.015, p<0.01]$ and the unemployment rate $[\beta=0.083, p<0.01]$.

The post-sale statute regression results for subprime-loan foreclosure starts presented in Table 2 indicate a $\mathrm{R}^{2}=0.787$, which implies that a 78.7 percent of subprime-loan foreclosure starts is explained by the regression model and that percent share explained is statistically significant $[(\mathrm{F}(20,285)=52.59, p<0.01]$. The right to re$\operatorname{deem}[\beta=0.227, p<0.05]$ is the only statistically significant post-sale protection statute in the subprime foreclosure start model. Three borrower characteristics are significant including percentage of white borrowers $[\beta=$ 0.026, $p<0.05]$ and percentage of Native America borrowers $[\beta=-0.121, p<0.05]$. Four of the mortgage/lending characteristics are statistically significant which include the percentage of loans with no income verification [ $\beta=0.032, p<0.01$ ], percentage of loans with non-owner occupancy [ $\beta=0.023, p<0.05]$, percentage of loans denied [ $\beta=0.068, p<0.01]$ and percentage of adjustable loans $[\beta=0.049, p<0.01]$. Two of the economic conditions are statistically significant including the change in house price index $[\beta=-0.088, p<0.01]$ and the unemployment rate $[\beta=0.050, p<0.05]$.

\section{Discussion and Conclusion}

Foreclosure starts increase more than doubled from 2004 to 2009, up from 0.432 percent to 1.06 percent. To help tackle this problem, policymakers established a number of statewide foreclosure protection statutes to help financially distressed mortgage borrowers keep their homes. Our paper investigates the extent to which statewide foreclosure-prevention statutes impact foreclosure starts. Four of ten foreclosure protection statutes have a statistically significant impact on foreclosure starts. The pre-sale foreclosure statutes have more of an impact on foreclosure starts than the post-sale statutes.

Of the pre-sale protection statutes, the Housing Emergency Assistance Funds (HEAF), decrease foreclosure starts and may help financially distressed families keep their homes. HEAF is statistically significant for prime 
and subprime mortgage loans. HEAF can vary across states. In general, these programs are designed to provide assistance to homeowners experiencing temporary financial difficulties such as loss of employment, illness, disability, death, divorce or legal separation. For homeowners specifically impacted by the foreclosure crisis, HEAF can provide: 1) assistance to homeowners with monthly mortgage payments for a period of one to two years; and 2) below market rate loans to be repaid when the home is sold, transferred, refinanced or designed as revolving funds, with amounts replenished by loan repayment.

Two other statistically significant pre-sale statutes, Loss Mitigation Requirement Before Foreclosure (LMRF) and Personal Service Requirement for Complaint or Sale Notice (PSRCSN) increase the percentage of foreclosure starts for prime borrowers. Loss mitigation is a process used by mortgage lenders to work with buyers who are delinquent on their home loans. Through the loss mitigation process, a lender may modify the terms of a home loan. These new terms are typically obtained through loan modification, short sale negotiation, refinance negotiation, deed in lieu of foreclosure, cash-for-keys negotiation, a partial claim loan, repayment plan, forbearance, or other loan workout. All of the options serve the same purpose, to stabilize the risk of loss the lender is in jeopardy of realizing. A direct relation was found between loss mitigation and foreclosure starts for prime loans. This result is somewhat surprising since loss mitigation should help borrowers to obtain a financially sustainable solution to remain in their homes and avoid foreclosure. A two-fold explanation of the positive sign is offered. First, there is often a delay involved with the implementation of effectual mitigation programs. Thus, homeowners fail to realize loss mitigation benefits. Second, loss mitigation might increase homeowner awareness of looming foreclosure and ultimately lead to more timely decisions to start the process.

Personal Service Requirement obligates the lender to directly serve homeowners with the notice of sale or foreclosure complaint. These state laws require that no matter which type of foreclosure proceeding is permitted, the mortgage holder must provide proof of personal service of the legal documents which both commence the foreclosure proceeding and schedule the sale, or the mortgage holder must document repeated good faith attempts to make personal service on the homeowners. Personal Service increases foreclosure starts for prime loans. This relationship is expected since personal service guarantees actual notice to a defendant of a legal action against him or her. Thus, homeowners come to terms with the legal homeownership battle they face. This realization often leads to more timely decisions to start the foreclosure process.

The post-sale protection decree, Right to Redeem (RTR) is the only statistically significant post-sale foreclosure statute. This law provides homeowners with a statutory right to reacquire title to their home, for a fixed period of time after a foreclosure sale. The homeowner can regain the title to the home by paying the sale price, interest and costs of the sale. This payment compensates the mortgage holder or other purchaser for their financial outlay. The right to redeem increases foreclosure starts for subprime loans. RTR provides the homeowners with an opportunity to recover their home; as a result homeowners opt out of tactics to delay and start the foreclosure process.

In conclusion, statewide foreclosure-prevention statutes impact foreclosure starts. The results indicate that housing emergency assistance funds (HEAF) is the only statute that statistically slows foreclosure starts. Additionally, this paper lays the foundation for future cost-benefit investigations of foreclosure-prevention statutes.

\section{References}

Baker, M. J., Miceli, T., \& Sirmans, C. F. (2008). An Economic Theory of Mortgage Redemption Laws. Real Estate Economics, 36, 31-45. http://dx.doi.org/10.1111/j.1540-6229.2008.00205.x

Bureau of Labor Statistics, Local Area Unemployment Rates by States. http://www.bls.gov/web/laus/laumstrk.htm

Collins, J. M., Lam, K., \& Herbert, C. (2011). State Mortgage Foreclosure Policies and Lender Interventions: Impacts on Borrower Behavior in Default. Journal of Policy Analysis and Management, 30, 216-232.

http://dx.doi.org/10.1002/pam.20559

Experian (2014). State of Credit. http://www.experian.com/live-credit-smart/state-of-credit-2014.html

Federal Financial Institutions Examination Council (2014). Aggregate Report Search by State.

https://www.ffiec.gov/hmdaadwebreport/aggwelcome.aspx

Federal Financial Institutions Examination Council (2013). A Guide to HMDA Reporting Getting It Right! http://www.ffiec.gov/hmda/pdf/2013guide.pdf

Federal Housing Finance Agency (2014). House Price Index. http://www.fhfa.gov/DataTools/Downloads/Pages/House-Price-Index.aspx 
Federal Housing Finance Agency (2015). Monthly Interest Rate Survey, Table 15: Terms on Convention Single-Family Mortgages by State. http://www.fhfa.gov/DataTools/Downloads/Pages/Monthly-Interest-Rate-Data.aspx

Goodman, A. C., \& Smith, B. C. (2010). Residential Mortgage Default: Theory Works and So Does Policy. Journal of Housing Economics, 19, 280-294. http://dx.doi.org/10.1016/j.jhe.2010.09.002

Koc, C. D., Dudley, E., \& James, C. M. (2014). State Foreclosure Laws and the Incidence of Mortgage Default. Journal of Law and Economics, 57, 225-280. http://dx.doi.org/10.1086/674868

Mortgage Banker Association (MBA) (2014). Delinquency and Foreclosure Rates Continue to Improve. http://www.mbaa.org/NewsandMedia/PressCenter/88228.htm

Pence, K. M. (2006). Foreclosing on Opportunity: State Laws and Mortgage Credit. The Review of Economics and Statistics, 88, 177-182. http://dx.doi.org/10.1162/rest.2006.88.1.177

Quercia, R. G., \& Ding, L. (2009). Loan Modifications and Re-Default Risk: An Examination of Short-Term Impacts. Journal of Housing Economics, 11, 171-193.

Rao, J., \& Walsh, G. (2009). Foreclosing a Dream: State Laws Deprive Homeowners of Basic Protection. National Consumer Law Center, Inc. http://www.nclc.org/images/pdf/pr-reports/report-foreclosing-dream.pdf

Schill, M. H. (1991). An Economic Analysis of Mortgagor Protection Laws. Virginia Law Review, 77, 489-538. http://dx.doi.org/10.2307/1073360

U.S. Bureau of Economic Analysis (2014). State or DC SA1-3 Personal Income Summary. http://www.census.gov/construction/bps/stateannual.html

US Census Bureau (2014). Building Permits Survey. http://www.census.gov/construction/bps/stateannual.html 